pleased to give and grant unto Surgeon-Captain RICHARD CHARLES KIRBY LAFFAN, Army Medical Staff; Her Majesty's royal licence and authority that he may accept and wear the insignia of the Order of the Osmanieh
of the Third Class, which His Highness the Khedive of Egypt, authorised of the Third Class, which His Highness the Khedive of Egypt, authorised
by His Imperial Majesty the Sultan, has been pleased to confer upon him in recognition of his services whilst actually and entirely employed beyond Her Majesty's dominions in the service of His

spector of Hospitals to the Egyptian Sanitary Department. An exchange has been sanctioned between surgeon-Captain H. A. DE Bombay Establishment.

Surgeon-Captain H. A. DE LOM, just arrived from England, is posted to Bombay District for general duty.

Surgeon-Lieutenant-Colonel W. B. SLAUGHTER and Surgeon-Captain J. w. CocKERILL, who are serving in the Madras command, have leave of absence, the former for one month on private affairs in extension, the sion.

Administrative medical officers in charge of military districts will in future be styled Principal Medical Officers, and those senior in stations where administrative officers are not found will be known as Senior Medical Officers.

The following Surgeon-Captains, having completed, on July 31st, twelve years' service, attain the rank of Surgeon-Major: G., H. SYLVESTER, W. J. MACNAMARA, M.D., D. O'SULLIVAN, E. O. MILWARD, C. R. WOODS, M.D., M. RAY, M.B., M. W. KERIN, A. PETERKIN, M.'B., J. HARRAN, E. L̈. MAUNSELL, W. HEFFERNAN, R W. E. H. NICHOLSON, J.' G. W. CROFTS, W. DUGDALE,
D. L. IRVINE, E. R. CREE, M. O'C. DRURY, J. H. NICHOLAS, D. F. FRANK-

D. L. IRVINE, E. R. CRE

Surgeon-Captain William Halloran BenNetT, M.B., died at Longford, suddenly, on July 29 th, in his 33 rd year. He was the second son of the
late Major-General $R$. Bennett, of the 46th Regiment, and was appointed late Major-General R. Bennett, of

Surgeon-Major WILIIAM BARRETT, M.B., late of the 71st Regiment, died at Edinburgh on August 1st at the age of 76 . He was appointed Assistant Major, December 18th, 1864; and retired from the service, June 20th, 1865,

\section{INDIAN MEDICAL SERVICE.}

SuRgeon-Captain A. H. Notr, Bengal Establishment, is appointed to act as civil surgeon of Hooghly.

Surgeon-Captain J.T. CALVERT, Bengal Establishment, is appointed to act as civil surgeon of Chittagong during the absence of surgeon-Lieutenant-Colonel W. F. Murray.

Surgeon-Captains J. G. JORDAN and T. GRAINGER, of the Bengal Establishment, received charge on June 8th of Jessore Gaol and Champarun Gaol respectively.

Surgeon-Captain W. H. GRAY, Bengal Establishment, assumed charge of the civil medical duties of Dera Ismail Khan on June 4th, relieving Surgeon-Captain C. E. Sunder.

Surgeon-Lieutenant R. K. MITTER, Madras Establishment, has passed the examination in Hindustani by the lower standard.

ment, Civil Surgeon of Lucknow, is appointed to hold visiting medical charge of the Hardoi District, in additi

Brigade-Surgeon-Lieutenant-Colonel, R. JAXresoN, M.D., Bengal Establishment, Deputy Sanitary Commissioner, on return from furlough, is appointed to the 1st Circle, comprising the Agra and Meerut Divisions.

ment officiating Superintendent of Lucknow Central Prison, are placed at ment, officiating Superintendent of Lucknow Central Prison, are place
the disposal of the Government of India in the Home Department.

Surgeon-Captain R. ROBERTSON, Madras Establishment, is appointed to act as Second Surgeon Madras General Hospital, and as Professor of act as Second Surgeon Madras General Hospital, and

Surgeon-Captain H. W. STEVENSON, Bombay Establishment, Superintendent of Mahableshvar, in the District of Satara, is appointed a magistrate of 2nd class in that district, and will exercise the powers with which he is hereby invested within the limits of the Hill station of the MahabSection 62 of Bombay District Police Act IV of 1890 .

The undermentioned officers have been granted leave of absence as specified :-Surgeon-Lieutenant-Colonel WirsoN, M.D., Bengal Establishment, civil surgeon of Hazareebagh. for one year on medical certificate; Surgeon-Captain J. M. CADELL, M.B., Bengal Establishment, 11th Bengal Infantry, for four months on private affairs ; Surgeon-Major G. A. CoNB8, Bengal Establishment, 2nd Queen's Own Bengal Light lnfantry, to proceed to England on medical certificate; Surgeon-Major W. OwEN, Bengal Establishment, Factory Superintendent Behar Opium Agency, privilege leave for three months on private affairs; Surgeon-Captain P. C. H. geon-Major F. F. MACCARTIE, M.B., Bombay Establishment, Headth Officer of Port of Bombay, private leave for three months from date of SurgeonCaptain Crimmin's return from leave, or from such subsequent date as he may avail himself of it: Surgeon-Captain J. G. HOJEL, M.B. Bombay Establishment, medical officer sth

months on medical certificate. Surgeon-Captain T. E. DYSON, M.B., Bombay Establishment, received charge of the office of Deputy Sanitary Commissioner, Goojerat Registration District, on June 20th

Surgeon-Major DANIEL KEARNEY, Retired List, Madras Establishment, died at his residence, Richmond Town, Bangalore, aged 63, from a stroke of paralysis. The deceased gentleman originally belonged to the SubCaptaln Moore, Her Majesty's 35 th Foot, in the Zonuzafun District, against the insurgent Minloung. He then proceeded to England, and competed for the Indian Medical Service, and in 1860 was appointed an assistant surgeon, and posted to do duty in the General Hospital, Madras. After
completing eighteen years' service he retired on July 1st, 1878, with the rank of surgeon-major, and settled in Bangalore.

Surgeon-Major H. HAMILTON, Bengal Esta'blishment, is transferred, at his own request, from the medical charge of the 10th Bengal Infantry to Ranking. Surgeon-Captain D. G. MARSHaLL, Bengal Establishment, is appointed to the officiating medical charge of the Bengal Sappers and Miners, vice Surgeon-Lieutenant-Colonel J. Young.

Surgeon-Lieutenant-Colonel
Surgeon-Captain C. H. JAMS, Bengal Establishment, is transferred from the officiating medical charge of the 20th Punjab Infantry to the officiating medical charge of the 3rd Sikh Infantry, vice Surgeon-Captain J. T. Calvert

Surgeon-Lieutenant B. G. SEToN, Bengal Establishment, is appointed to Captain A. H. Nott Surgeon-Captain H. SMrrH, Bengal Establishment, is appointed to the
officiating medical charge of the 2nd Battalion 1st Goorkha Rifles, vice Surgeon-Lieutenant-Colonel R. N. Stoker.

Surgeon-Lieutenant-Colonel E. PALMER, Bengal Establishment, has leave of absence to the hills, on medical certificate, for five months.

Surgeon-Major H. ST. C. CARRUTHERS, Madras Establishment, is granted special leave, on urgent private affairs, for six months.

ARMY MEDICAL RESERVE.

SURGEON-MAJOR G. S. ELLISTON is promoted to be Surgeon-LieutenantColonel.

THE VOLUNTEERS.

SURGEON-LIEUTENANT J. CUNNINGHAMr, M.B., 1st Argyll and Bute Artillery, is promoted to be Surgeon-Captain, July 23 rd.

Surgeon-Lieutenant J. R. THOMAS, M.D., 4th Volunteer Battalion the Devonshire Regiment (late the 4th Devonshire), is promoted to be Surgeon-Major, July 23rd.

Surgeon-Lieutenant J. H. EDWARDS, M.D., 1st Surrey (South London),

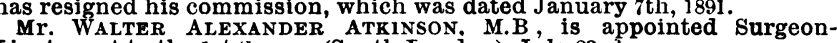
Mr. WALTER ALEXANDER ATKINSON. M.B. B, is appoin
Lieutenant to the 1st Surrey (South London). July $23 \mathrm{rd}$.

Mr. THOMAS NESBITT WRIGHT is appointed Surgeon-Lieutenant to the 2nd Volunteer Battalion Queen's Own Royal West Kent Regiment (formerly the 3rd Kent), July 23 rd.

The undermentioned Surgeon-Lieutenants have resigned their commissions: R. H. JONES, 6th Lancashire Artillery, dated June 28th, 1882; D. L. HUBBARD, 1st Cheshire and Carnarvonshire Artillery, August 1lth, (late the 4th West Riding), November 29th, 1890 .

Surgeon-Captain W. STEPHENSON, 2nd Volunteer Battalion East Yorkshire Regiment (late the 2nd East Riding), is promoted to be Major, July 30 th.

Surgeon-Captain K. MACLEAN, 4th Volunteer Battalion Cheshire Regi-
thent (late the 4th Cheshire), has resigned his commission, which was dated February 1st, 1889.

Erratum.-In the British Medical Journal of June 11th, SurgeonCaptain F. E. FENTON was erroneously described as Surgeon-Lieu-

VOLUNTEER MEDICAL STAFF CORPS

THE annual inspection of the Norwich company of the Volunteer Medical Staff Corps took place on July 21st. The officers on parade were SurgeonCaptain Richardson, Surgeon-Lieutenant Cosens, and Captain Mills. At the close of the inspection, Surgeon-Colonel Giraud, P.M.O. Eastern
District, who conducted it, expressed himself well pleased with the drill bistrict, who conducted it, exp
both at the barracks and field.

ASSOCIATION OF MEDICAL OFFICERS OF THE MILITIA OF THE first annual meeting of the Association of Medical Officers of the Militia of Canada, was held at the Canadian Military Institute at Toronto, stitution and by-laws had been adopted, an address was delivered by the President, in which he said, that for the twenty-six years during which the militia of Canada, as at present organised, had existed, the medical officer of a battalion had been but a regimental unit. One of the objects of the Association was, by binding these units together, to give them their proper place in the military history of their country, and to impart an interest and an increased efficiency in the performance of the work n which they were engaged. object of the Association, however, was the furtherance of professional knowledge. The reading and discussion of papers on military medicine, surgery, and hygiene, had hitherto received no attention in Canada. Among the communications presented to the meeting were the following: “Ambulance Work during the Franco-Prussian War," by Dr. Warren: "Some Brain Wounds, with Results," by Dr. Daniel "Clark. some time Inspector of Surgery in the United States Army ; and " "Some
of a Surgeon during the American War," by Dr. Wm. Canniff.

AMBULANCE ChALLENGE SHIELD.

THE competition for the Ambulance Challenge Shield of the Volunteer Medical Association, which was open to regiments of Yeomanry Cavalry to Volunteer Corps, and to the Honourable Artillery Company, took place on July 16 th at Wellington Barracks. The examining officers were and Surgeon-Major Watson and Sureeon-Captain J. E. Squire, London and Companles Volunteer Medical staf Corps. Amongst other oncers precurreor surgeons of the East London and Surrey Brgades; Surgeon- Majors Cake Captains H. F. Stokes, Senior Medical Officer Instructor, Volunteer Am-
bulance School of Instruction; W. H. Bull, Knott, R. Sleman, St. Clair 